\title{
Planos nacionais de reforma agrária: uma leitura a partir dos movimentos sociais
}

Submetido em: 30/11/2019, aprovado em: 13/03/2020

10.30612/mvt.v7i13.10762

Claudinei Lucio Santos ${ }^{1}$

Alex Sandro Possamai da Silva ${ }^{2}$

\begin{abstract}
RESUMO: A Reforma Agrária sempre foi pauta de calorosos debates no mundo político e acadêmico brasileiro. Apesar de profundas pressôes sociais e da criação de legislaçóes a terra nunca foi distribuída de forma democrática no Brasil. $\mathrm{O}$ trabalho aqui desenvolvido tem por objetivo realizar um esforço em descrever sobre os três Planos Nacionais de Reforma Agrária propostos no sentido de executar as medidas estabelecidas no Estatuto da Terra. Descreve-se, nesta seara, o contexto político em que tais planos foram criados, bem como seus limites e fracassos que elevaram a Reforma agrária a um patamar de questão insolúvel até os dias atuais.
\end{abstract}

Palavras-chave: Reforma Agrária. Planos. Estatuto da Terra.

\section{National plans for agrarian reform: a reading from social movements}

ABSTRACT: Agrarian Reform has always been a hot topic of debate in the Brazilian political and academic world. Despite deep social pressures and the creation of legislation land has never been democratically distributed in Brazil. The objective of the work developed here is to make an effort to describe the three proposed National Agrarian Reform Plans in order to implement the measures established in the Land Statute. The political context in which these plans were created is described, as well as its limits and failures, which have raised Agrarian Reform to the point of an insoluble question to the present day.

Keywords: Agrarian Reform. Fight for land. National Plans. Statute of the Earth. Constitution.

\footnotetext{
1 Militante do MST- RO e Via Campesina, Bacharel em Direito pela Universidade Estadual de Feira de Santana (UEFS) - BA, e membro do Instituto Territórios e Justiça INTERJUS. claudineisantos@mst.org.br 2 Ji-Paraná - RO, Advogado Popular, graduado em direito pelo PRONERA, Turma Elizabeth Teixeira na Universidade Estadual de Feira de Santana - BA (UEFS). Filho de assentados da Reforma Agrária, militante do MST, compóe o Setor de Formação e Direitos Humanos da organização. Integrante do INTERJUS - Instituto Territórios e Justiça e da RENAP - Rede Nacional dos Advogados e das Advogadas Populares. Orcid: https://orcid.org/0000-0001-8705-1182
} 


\title{
Planes nacionales de reforma agraria: una lectura desde los movimientos sociales
}

RESUMEN: La Reforma Agraria siempre ha sido objeto de acalorados debates en el mundo político y académico brasileño. A pesar de las profundas presiones sociales y la creación legislativa, la tierra nunca ha sido distribuida democráticamente en Brasil. El trabajo desarrollado aquí tiene como objetivo hacer un esfuerzo para describir los tres Planes Nacionales de Reforma Agraria propuestos para implementar las medidas establecidas en el Estatuto de la Tierra. Describe se, en este sentido, el contexto político en el que se crearon tales planes, así como sus límites y fracasos que elevaron la reforma agraria a un nivel insoluble hasta el día de hoy.

Palabras clave: Reforma Agraria. Planes. Estatuto de la tierra.

\section{INTRODUÇÃO}

No dia 13 de março de 1964, houve na Central do Brasil - Estado do Rio de Janeiro, o famoso comício onde João Goulart, então presidente da República, anunciou diante de um público de mais de 100 mil pessoas, que estaria enviando para o Congresso Nacional, uma mensagem propondo um Projeto de Lei de Reforma Agrária. Neste estava previsto que todas as propriedades acima de 1.000 hectares que estivessem ao longo das rodovias federais, seriam desapropriadas para fins de Reforma Agrária. Assim bradou Jango:

\begin{abstract}
O que se pretende com o decreto que considera de interesse social, para efeito de desapropriação, as terras que ladeiam eixos rodoviários, leitos de ferrovias, açudes públicos federais e terras beneficiadas por obras de saneamento da Uniáo, é tornar produtivas áreas inexploradas ou subutilizadas, ainda submetidas a um comércio especulativo, odioso e intolerável. Não é justo que o benefício de uma estrada, de um açude ou de uma obra de saneamento vá servir aos interesses dos especuladores de terra, que se apoderaram das margens das estradas e dos açudes. A Rio-Bahia, por exemplo, que custou 70 bilhóes de dinheiro do povo, não deve beneficiar os latifundiários, pela multiplicação do valor de suas propriedades, mas sim o povo. [...] A Reforma Agrária não é capricho de um Governo ou programa de um partido. É produto da inadiável necessidade de todos os povos do mundo. Aqui, no Brasil, constitui a legenda mais viva da esperança do nosso povo, sobretudo daqueles que labutam no campo. (STÉDILE, 2005. p.146).
\end{abstract}

No entanto, tais proposiçôes, iam contra os interesses das oligarquias, e no dia 31 de março daquele mesmo ano, João Goulart veio a sofrer um Golpe Militar que assaltou por mais de vinte anos a democracia no Brasil. Tal fato evidencia o quão de heresia existia em torno da Reforma Agrária no Brasil deste período.

Contudo, também expressa a necessidade de sua implementação, bem como a pressão popular em relação à temática.

A criação do Estatuto da Terra, mesmo no período em que o poder estava nas mãos dos militares cuja ascensão deu-se justamente para abafar a ânsia por Reforma agrária que rondava a sociedade brasileira, evidencia a fervura social acerca da necessidade de distribuição das terras no Brasil. 
Fruto do Estatuto da Terra criou-se os Planos Nacionais de Reforma Agrária, ambicionando, consequentemente a executar as medidas estabelecidas no referido documento.

Diante da importância desta temática cuja concretude nunca ocorreu, o trabalho aqui desenvolvido finca-se no objetivo de descrever os Planos Nacionais de Reforma Agrária. Neste sentido, ambiciona-se alimentar o debate para que a Reforma Agrária não seja jogada ao esquecimento como deseja uma pouca parcela da sociedade.

Para tanto, partiremos das premissas e dos marcos fundamentais estabelecidos pela Constituição de 1988 que dispôs (art. 5 , XXII, XXIII) a propriedade e a função social como direitos fundamentais. Desta forma, estabeleceu que fosse assegurado o direito de propriedade desde que tal propriedade cumprisse com sua função social. Assim, aqueles imóveis que não cumprisse a função social, deveriam ser desapropriados para fins de Reforma Agrária (art. 184). Ou seja, falar em Reforma Agrária pressupõe, também, dar sentido ao Texto Constitucional.

No encalço de realizar a empreitada aqui proposta o presente trabalho encontra-se dividido em três tópicos, onde fazemos uma descrição histórica acerca dos três planos nacionais de Reforma Agrária propostos nos governos de José Sarney, Fernando Henrique, e Lula.

\title{
PRIMEIRO PLANO NACIONAL DE REFORMA AGRÁRIA: (JOSÉ SARNEY 1985-1989)
}

\author{
A classe roceira e a classe operária \\ Ansiosas esperam a reforma agrária \\ Sabendo que ela dará solução \\ Para situação que está precária. \\ Saindo projeto do chão brasileiro \\ De cada roceiro ganhar sua área \\ Sei que miséria ninguém viveria \\ E a produção já aumentaria \\ Quinhentos por cento até na pecuária! \\ (Grande Esperança. Zilo e Zalo, 1989³)
}

Em 1985, dado o processo de resistência e desgaste do período totalitário, o Brasil marchava para o "fim" da Ditadura Militar. Como parte dos acordos do processo de transição, Tancredo Neves, eleito pelo Colégio Eleitoral, assumiu o compromisso de priorizar e ampliar o projeto de

3 A música que refletia o momento político e embalou as lutas deste período. 
Reforma Agrária. Para isso, convidou José Gomes da Silva para ocupar a presidência do INCRA (MORISSAWA, 2001), além disso, criou o Ministério da Reforma Agrária (MIRAD) e, por indicaçáo dos bispos da regiáo Norte, convidou para ocupar o cargo de ministro, Nelson Ribeiro, paraense, conhecedor dos problemas fundiários daquela região e que era apoiado por grande maioria dos movimentos sociais.

Contudo, em que pese o compromisso assumido por Tancredo, a história ainda colocaria grandes desafios para os movimentos sociais. Isso porque o futuro presidente morreu antes de tomar posse, assumindo o governo o vice-presidente José Sarney que manteve o programa.

Em maio de 1985, o MIRAD/INCRA, sobre o comando de José Gomes da Silva e Nelson Ribeiro, encaminhou para o Congresso Nacional e aos presidentes dos partidos políticos, a proposta ${ }^{4}$ para a elaboração do Plano Nacional de Reforma Agrária (PNRA) da Nova República.

Ainda em maio daquele mesmo ano, o presidente José Sarney, acompanhado de ministros vai até o IV Congresso Nacional da Confederação Nacional dos Trabalhadores na Agricultura (CONTAG) e lança a Proposta do Plano, provocando reaçóes distintas de diferentes segmentos sociais e da própria base do governo.

O programa básico do PNRA era o de assentamentos de trabalhadores em imóveis desapropriáveis [tendo como base para indenizar os proprietários fundiários o imposto territorial rural - valor declaradamente mais baixo que o de mercado]. Colonização, regularização fundiária e mecanismos tributários, até então apresentados como alternativas à obtenção de terras por diversas das forças presentes no debate político, apareciam como mecanismos complementares [à desapropriação] (MEDEIROS, 2003, p.35).

Silva (1985, p. 14), diz ser possível identificar na polêmica provocada pela proposta, pelo menos dois tipos de argumentos: "os interesses de classe e as motivações ideológicas". Tais argumentos tiveram lugar de destaque na luta política, pois permitiu identificar os grupos contrários e favoráveis à proposta: "Para ele, estava estabelecida uma divisão entre os que se colocaram contra, sendo de um lado, aqueles que não aceitavam a Reforma Agrária; e de outro, os que não aceitavam a proposta de Reforma Agrária do MIRAD/INCRA” (SILVA, 1985).

Sobre tais posicionamentos, faz a seguinte classificação:

No primeiro grupo estão os radicais de direita, próximos ao grupo da Sociedade Brasileira de Defesa da Tradição, Família e Propriedade (TFP), que defendem o direito inalienável da propriedade privada, e a Confederação Nacional da Agricultura (CNA), que congrega os grandes produtores rurais.

No segundo grupo, classifica os que são contra "a ideia da desapropriação por interesse social [...] que no fundo o que está por trás é a forma de pagamento, exigindo que seja em dinheiro. Para ele, este grupo era composto pelos produtores rurais, não necessariamente latifundiários no sentido de possuírem terras ociosas como reserva de valor. (SILVA, 1985, p. 14).

\footnotetext{
4 É preciso destacar que houve uma grande transformação da Proposta de Plano apresentada por José Gomes da Silva, em relaçáo ao plano assinado pelo presidente José Sarney. A discrepância foi tamanha que na época, o presidente do INCRA pediu demissão logo após a assinatura do decreto que aprovou o Plano. Esse episódio ficou registrado na história da Nova República por meio da foto onde José Gomes mostra a língua ao se demitir.
} 
Entretanto, ele ressalta que havia também o grupo que apoiava a proposta: este grupo era composto pelo Movimento Sindical de Trabalhadores Rurais, representados majoritariamente pela CONTAG, pela Associação Brasileira de Reforma Agrária (ABRA) e também pelos trabalhadores urbanos que por meio de seus sindicatos e federaçóes apoiavam a proposta. (SILVA, 1985).

Mesmo sendo um movimento ainda novo, do ponto de vista orgânico, o MST se coloca neste debate, como uma espécie de "herdeiro" de movimentos camponeses como Movimento de Agricultores Sem Terra (MASTER), União dos Lavradores e Trabalhadores Agrícolas do Brasil (ULTABS) e das Ligas Camponesas, e por isto tinha clareza, que a correlação de forças compostas pelo latifúndio e poder econômico, seriam contra qualquer proposta de Reforma Agrária no Brasil para aquela época. Entretanto, se coloca na disputa como forma de se consolidar como movimento social, propondo uma reforma de alta intensidade e fez isto inclusive contribuindo com algumas sugestôes para melhorar a proposta. Porém, considerava a proposta do governo muito tímida e sugeriu sua ampliação. Entre outras alterações, o MST sugeriu a desapropriação indistinta de todos os latifúndios e o estabelecimento de um módulo máximo para as propriedades rurais.

Representantes de proprietários de terras se reuniram em Brasília um mês após o anúncio do Plano e realizaram um congresso nacional para discutir o Plano apresentado pelo MIRAD/INCRA. Foi deste congresso que nasceu uma nova organização de representação de seus interesses. Esta organização foi a União Democrática Ruralista (UDR) .

Essa organização orientava aos seus associados que usassem a força no combate às ocupaçóes de terra. Também, passaram a disputar espaço com as entidades tradicionais como a Confederação Nacional de Agricultura - CNA e a Sociedade Rural Brasileira - SRB.

A UDR foi ganhando espaço nos meios de comunicação e passou a ser a principal porta-voz dos deputados ruralistas no Congresso Nacional. Diante de tanta pompa, a UDR saiu de coadjuvante para se tornar protagonistas na frente política institucional, passando a eleger seus associados para o parlamento ${ }^{6}$.

O que se tinha nesta proposta de Reforma Agrária, que fez com que as forças a favor e contrárias tivessem tamanha reação?

Em Dissertação Albuquerque (2006) faz seus apontamentos sobre os principais pontos do Plano:

1- Objetivo: Mudar a estrutura fundiária do país; distribuir a terra eliminando progressivamente o latifúndio e o minifúndio, assegurando um regime de posse e uso segundo os princípios de justiça social. Além de almejar alteraçóes na estrutura fundiária, a proposta pretendia aumentar a oferta de alimentos, criar novos empregos, ampliar o mercado interno e diminuir o êxodo rural.

2- Metas: Até o final do mandato do Presidente José Sarney, a proposta previa o assentamento de 1.400.000 famílias de sem-terra ou com pouca terra, deixando 5.700.000 de beneficiários para serem assentados até o ano 2000.

\footnotetext{
5 A UDR teve como seu principal articulador, o ruralista e Ortopedista e na época deputado federal Ronaldo Caiado (antigo PFL e hoje DEM - GO). A entidade na década de 80 foi muito forte e manteve vários escritórios seus no país. Foi extinta em 1994 e rearticulada dois anos depois em Presidente Prudente (SP) e Paranavaí (PR), duas regiôes de conflito por terra.

6 Frutos desta guinada política que vai ser operado com muita força depois dos massacres de Corumbiara e Eldorado dos Carajás, os interesses da UDR, são representados definitivamente pela Bancada Ruralista. A Bancada Ruralista é formada por parlamentares que atuam em conjunto no Congresso Nacional para defender os interesses dos proprietários de terras. Este grupo de parlamentares suprapartidário, alinhados nas votaçóes que dizem respeito aos seus negócios e investimentos. A força desse bloco fica mais evidente nos momentos em que se discute a Reforma Agrária nacionalmente. Na ocasião da Assembleia Constituinte a bancada ruralista foi orientada pela UDR, comandada pelo deputado Federal Ronaldo Caiado de Goiás.
} 
3- Estratégia de Ação: o MIRAD/INCRA definia a arrecadação de áreas por meio dos artigos do Estatuto da Terra, utilizando como principal instrumento o critério da função social da propriedade. O objetivo era atingir as áreas de domínio privado, situadas em regiôes já ocupadas, com infraestrutura e com razoável densidade demográfica. (Albuquerque, 2006, p. 58-59).

Entretanto talvez, o maior incômodo dos grupos de oposição, se dava por conta de duas propostas, a saber:

1- A proposta também recuperava o conceito, presente no Estatuto da Terra, da seleção de áreas prioritárias de reforma agrária, o que apontava para a possibilidade de transformaçóes fundiárias em áreas mais amplas e não somente de intervençôes pontuais, em focos de conflito.

2- Estava prevista também a participação das organizaçôes representativas dos trabalhadores rurais em todas as fases do processo. Nesse momento, a CONTAG era a mais expressiva delas. Além disso, seu forte apoio à Nova República lhe garantia um papel relevante nas decisóes a serem tomadas. (ALBUQUERQUE, 2006, p. 58- 59).

Por ter sofrido muitas alterações (12 ao todo) o primeiro Plano Nacional de Reforma Agrária se tornou em algo totalmente contrário do que José Gomes da Silva havia proposto e seus resultados foram uma tragédia. De (1985- 1989) foram assentadas apenas 83.687 famílias, cerca de 1\% do prometido (Publifolha, 2005). Para esses assentados foi criado pelo Conselho Monetário Nacional em 1985, (IPEA, 1999) o PROCERA (Programa de Crédito da Reforma Agrária), com o objetivo de garantir investimentos produtivos na terra.

Com a derrota do primeiro Plano Nacional de Reforma Agrária (PNRA) do ponto de vista das metas, a luta pela a Reforma Agrária se deslocou para a Assembleia Constituinte de 1988. No entanto a Reforma Agrária no contexto da Constituição morreu, respectivamente, de morte morrida e de morte matada. De morte morrida por que o artigo 186 que sugere a desapropriaçáo de áreas que não cumprem sua função social, casada com a Lei Agrária de 1993, abriu um caminho para que Judiciário intervenha nos processos de desapropriação, na medida em que o proprietário pode contestar o mérito em diferentes etapas da açáo, tendo o juiz o poder de arbitrar sobre despejos, valores de desapropriação, aprovação ou reprovação de relatório de produtividade e outros. E de morte matada, porque o artigo 185, que apontou as áreas produtivas como insuscetíveis de desapropriação, praticamente anulou o artigo 186.

Na década de 90, o tema da Reforma Agrária ficou na berlinda, principalmente durante o governo Fernando Collor de Melo/Itamar Franco. Este período vai até a metade do primeiro mandato do governo Fernando Henrique Cardoso. O debate em torno da economia, implantação do Plano Real e a meta de combate à inflação capitanearam todo o debate político ${ }^{7}$.

No governo Collor, o INCRA foi totalmente desarticulado, por conta da reforma administrativa que o governo promovia com a clara intencionalidade de inviabilizar a Reforma Agrária. Como saldo desta reforma, tivemos funcionários afastados, recursos da poupança contingenciados, assentamentos suspensos e desapropriaçóes inviabilizadas pela falta de regulamentação dos dispositivos

\footnotetext{
$7 \quad$ No governo de Fernando Collor (1990-1992), o programa de assentamentos foi paralisado, cabendo registrar que, nesse período, não houve nenhuma desapropriação de terra por interesse social para fins de reforma agrária. O governo de Itamar Franco (1992-1994) retomou os projetos de reforma agrária. Foi aprovado um programa emergencial para o assentamento de 80 mil famílias, mas só foi possível atender 23 mil com a implantação de 152 projetos, numa área de um milhão 229 mil hectares. No final de 1994, após 30 anos da promulgação do Estatuto da Terra, o total de famílias beneficiadas pelo governo Federal e pelos órgãos estaduais de terra, em projetos de reforma agrária e de colonização, foi da ordem de 300 mil, estimativa sujeita a correçōes, dada a diversidade de critérios e a falta de recenseamento no período 1964-1994.
} 
constitucionais, que só vira ocorrer em 1993. Com isto, o conflito no campo se agravou e cresceu o número de ocupações de terras improdutivas. Esse crescimento está relacionado à expansão e ao fortalecimento MST que inovou com sua forma de luta, fazendo das ocupaçóes de terra o principal instrumento de visibilidade política da Reforma Agrária.

Dado o agravamento dos conflitos no campo e a postura política do MST, abriu-se caminho para diálogos com os movimentos sociais e demais organizaçóes de apoio a luta pela Terra. Fruto disto é que o vice-presidente Itamar Franco recebe o MST e a CONTAG em audiências no Palácio do Planalto.

Mas diante do contexto político e econômico, prevaleceu a lógica da desapropriação de áreas em situação de conflitos, com o objetivo de eliminar os focos de tensão social.

\title{
SEGUNDO PLANO NACIONAL DE REFORMA AGRÁRIA: (FERNANDO HENRIQUE CARDOSO)
}

\author{
Esse é o nosso país \\ Essa é a nossa bandeira \\ É por amor a essa pátria Brasil \\ Que a gente segue em fileira \\ (Ordem e Progresso, Zé Pinto, 1997)
}

Fernando Henrique Cardoso assume a presidência da República em um período de grande assenso das lutas sociais no campo. Dado aquele momento da conjuntura, havia na sociedade um clamor pela efetivação da Reforma Agrária, e consequentemente o apoio aos movimentos de luta pela terra.

Entretanto, o debate sobre a Reforma Agrária era assunto periférico no início do seu primeiro mandato, que foi de 1995 a 1998. O governo tinha uma avaliaçáo, que a Reforma Agrária era coisa superada tanto no campo econômico quanto no campo ideológico, tratando o tema com açóes compensatórias, com o objetivo "controlar" os conflitos sociais no campo, demostrando assim sua contradição, pois se a Reforma Agrária era coisa superada, então porque aplicar açóes para controlar os conflitos? Quais os conflitos?

Em matéria veiculada na Folha de São Paulo, em 27/04/97, Tavares nos ajuda a entender qual era a postura do governo Fernando Henrique Cardoso a respeito da Reforma Agrária:

$\mathrm{Na}$ ótica do governo a reforma agrária teria perdido seu conteúdo histórico, tendo na atualidade escassa importância econômica e mesmo política. Por trás dessa visão está o argumento de que as mudanças recentes no país, ao desvalorizar a terra como ativo, fragilizaram o latifúndio [...] A conclusão implícita é que a

$8 \quad$ A música que refletia o momento político e embalou as lutas deste período. 
desmontagem da estrutura latifundiária se daria "naturalmente" por meio de "estímulos ao mercado de terras" e a intervenção estatal só seria requerida para solução de problemas e conflitos localizados. Esse diagnóstico do governo falsifica as questóes centrais, inclusive a natureza estrutural da necessidade da reforma. (TAVARES, 1997, p. 4).

Peres (2015) salienta que a estratégia do governo estava pautada no sufocamento e isolamento político da Reforma Agrária, e todos os movimentos de luta pela Terra, em especial do MST. Mas dado o processo de massificação das ocupações de latifúndio, dois acontecimentos interromperam esta estratégia, levando o debate sobre a Reforma Agrária no centro da pauta política. Um foi o Massacre de Corumbiara no estado de Rondônia em 1995, na gestão do hoje senador e na época governador, Valdir Raupp (MDB). Nesse massacre, a polícia militar invadiu o acampamento Santa Elina, durante à noite para realizar um ato de covardia e crueldade, com o objetivo de fazer o despejo daquelas famílias. Esta ação resultou no tombamento 12 pessoas - sendo 10 sem-terra e 2 policiais, deixando ainda uma centena de feridos, ente elas, crianças e idosos.

Outro foi o Massacre de Eldorado dos Carajás, no estado do Pará, em 1996. Nesse ano, cerca de 1000 pessoas entre trabalhadoras e trabalhadores sem-terra, bloquearam a rodovia PA-150, em uma manifestação de caráter reivindicatório. A polícia militar cercou a manifestação com um efetivo de aproximadamente 150 policiais, e sobre a determinaçáo expressa (NEPOMUCENO; 2007, p. 137) do então governador do estado, Almir Gabriel (PSDB), para desbloquear a rodovia a qualquer custo.

E para se cumprir aquela determinação judicial, a ordem do coronel Pantoja foi clara:

[...] liberar a estrada bloqueada por cerca de 2500 manifestantes do MST. Levaram pouco menos de quarenta minutos para cumpri-la, ao mesmo tempo, deixar a marca perene numa história salpicada de violência contra aquela gente miserável, muitas vezes faminta, que punha em jogo a vida para ter um pedaço de terra onde plantar, viver e morrer [...] (NEPOMUCENO; 2007, p. 120).

Esta ação, deixou como resultado a morte de 19 sem-terra.

Estes dois acontecimentos, fizeram com que viesse à tona a total violação de direitos de milhares de famílias sem-terra que se encontravam acampadas nas beiras de estradas e dentro dos latifúndios improdutivos. Nesse sentido, o governo tratou logo de desenvolver açóes que dessem respostas para a sociedade brasileira e para a comunidade internacional, diante dos resultados desses dois massacres, ao mesmo tempo que pudesse fazer a disputar política e ideológica da Reforma Agrária, e passou a se valer do seguinte discurso, "Reforma Agrária, Compromisso de todos". E para isto, precisou tomar medidas administrativa para dar consistência a esta disputa.

A primeira medida foi a criação do Ministério Extraordinário de Política Fundiária, (A NOVA REFORMA AGRÁRIA, 1999, p.2) sendo o Instituto Nacional de Colonização e Reforma Agrária (INCRA) vinculado a este. Entretanto, sua incapacidade operacional não produziram as respostas necessárias para aquele momento. $\mathrm{O}$ indicado para dirigir a pasta, foi o atual ministro da justiça, Raul Jungmann, político já experiente, hábil negociador e filiado ao Partido Popular Socialista (PPS). 
No aniversário de um ano de sua criação, o MEPF deixa de existir, vindo a se transformar no já extinto pelo (des) governo Michel Temer, no Ministério do Desenvolvimento Agrário (MDA). Nascendo assim, o que podemos chamar de primeira parte do Plano Nacional de Reforma Agrária do governo Fernando Henrique Cardoso.

A proposta de Plano era composta das seguintes açóes: (Id., Ibid).

(a) assentar 280 famílias entre 1996 a 1998;

(b) criar linhas de crédito, como objetivo, garantir recursos subsidiados, metade dos quais o assentado não terá que devolver ao governo, para financiar todo o processo produtivo: custeio da lavoura, investimentos e pagamento da quota-parte na cooperativa do assentamento a que pertence. Esses recursos não financiam, porém, a implantação da infraestrutura;

(c) criou o Projeto Lumiar, que previa a formação de equipes de assistência técnica e capacitação profissional, para orientar o desenvolvimento autônomo dos assentamentos;

(d) Projeto Emancipar, que previa a emancipação de todas as famílias assentadas.

Como tal programa não enfrentou os problemas de fundo no tocante a questão agrária e consequentemente da própria Reforma Agrária, o fim do primeiro governo de Fernando Henrique Cardoso, foi marcado por dois acontecimentos que marcou a história da luta pela terra no Brasil. Um de ordem política, e outro de ordem jurídica e administrativa. $\mathrm{O}$ de ordem política foi a marcha nacional do MST "Reforma Agrária, Emprego e Justiça” para Brasília, que tinha como objetivo disputar a concepçáo de modelo de campo e de Reforma Agrária na sociedade, tendo a participação de diversos assentados e assentadas de diferentes regiôes do país, chegando em Brasília em 17 de abril de 1997, depois de dois meses de caminhada, dia em que o massacre de Eldorados de Carajás completou um ano. Sendo está uma ação de longa duração, a mesma foi capaz de mobilizar elementos difusos que, em seu percurso, "produziu naquele momento" uma nova realidade social, ou seja, um redimensionamento da relação do MST com a sociedade e com o Estado. (CHAVES, 2000, p. 137). O de ordem jurídica administrativa foi a tentativa de minar a capacidade de organização e de mobilizaçáo do MST. Para isto, foi aprovaçáo do Decreto n. o 2250/97, se convertendo em 2000 na Medida Provisória n ${ }^{\circ}$ 2.027-38, que alterando o art. $2^{\circ}$ da Lei n 8.629/93, (REVISTA DE DIREITO AGRÁRIO, 2007.p 38) que determinou a proibição de vistorias em terras ocupadas e a exclusão de trabalhadoras e trabalhadores envolvidos nestas ocupações (MEDEIROS, 2002).

Este Decreto traz em seu artigo $4^{\circ}$. traz a seguinte redação:

O imóvel rural que venha a ser objeto de esbulho não será vistoriado, para fins do art. $2^{\circ}$ da Lei $n^{\circ} 8.629$, de 24 de fevereiro de 1993, enquanto não cessada a ocupação, observados os termos e as condiçôes estabelecidos em Portaria do Presidente do Instituto Nacional de Colonização e reforma Agrária - Incra.

Além disso, o decreto mantinha na página do MDA, uma lista com os nomes das trabalhadoras e trabalhadores envolvidos nas ocupaçóes.

O início do segundo governo de Fernando Henrique Cardoso é marcado por sua investida em esforços para a construção de uma "nova” concepção de Reforma Agrária, agora adequada à 
lógica de mercado, descentralizando as açóes de execução da Reforma Agrária, que até então, era de responsabilidade do (INCRA), passando a transferir tais açóes para as instituiçôes bancarias. Esta nova logica ficou conhecida como, "Novo Mundo Rural", também chamada pelos movimentos sociais de "Reforma Agrária de mercado". (Brasília, 1999. 47 p).

Com esta nova estratégia a Reforma Agrária entrou para a concepção econômica neoliberal, que o Banco Mundial (NEAD, 2006) impôs para a América Latina nos anos 90. Esta orientação, surge com as críticas feitas pelo Banco sobre os processos de Reforma Agrária desenvolvido com o comando do Estado, alegando forte burocratização e entrave ao pleno funcionamento do mercado fundiário. Para isto, o governo toma de empréstimo o programa "Cédula da Terra", que foi um projeto piloto desenvolvido no estado do Ceará em 1996. Naquele estado, o projeto oficialmente se chamava, "Projeto-Piloto de Reforma Agrária e Alívio à Pobreza", (RAMOS FILHO, 2008), e em 1998 tendo como base sua vitória eleitoral, ele aplica a política denominada de "Agricultura familiar, Reforma Agrária e desenvolvimento rural". Este programa, tinha como finalidade, a expansão da agricultura familiar e sua inserção no mercado. E foi da junção desses dois programas que surge o que se convencionou a chamar de o "Novo Mundo Rural", (ALBUQUERQUE, 2006).

Segundo (ALBUQUERQUE, 2006, p. 75) o "Novo Mundo Rural” serviu de:

A principal medida do governo para viabilizar esse projeto refere-se à mudança no sistema de arrecadaçáo de terras, privilegiando o Banco da Terra em detrimento das desapropriaçóes, ignorando o artigo 186 da Constituição Federal que prevê a função social da terra e a possibilidade de desapropriação caso essa não seja cumprida. Apesar disso, os documentos do MDA ainda mantinham a desapropriação como principal instrumento de acesso à terra, em franca contradição com a ação governamental.

Por tanto, o programa colocava em cheque, o mecanismo da desapropriação, e valorização das formas individuais de negociação da compra e venda da terra. Com estes mecanismos, o governo comemorou o assentamento de 579.733 famílias, ou seja, que segundo dados do INCRA, foi o dobro de assentamentos realizados durante os 30 anos anteriores da sua gestáo (MEDEIROS, 2003, p. 73).

Estes dados são contestados por diversas organizaçôes, que denunciam uma espécie de "turbinação" dos dados no sentido de criar uma falsa imagem dos efeitos da política fundiária de seu governo.

\section{TERCEIRO PLANO NACIONAL DE REFORMA AGRÁRIA: (LUIZ INÁCIO LULA DA SILVA)}

Marchar novamente é preciso/ para manter a esperança/ do povo sofrido e cansado/ mas pra lutar não se cansa/ em frente ó povo sofrido, homens, mulheres, crianças/ o sonho não é utopia/ no tremular das bandeiras/ presta atenção meu país/ desperta pra realidade/ o que está acontecendo no campo e na cidade/ só a força popular mudará a sociedade.

(Brasil em fileira. Oficina de música MST-2005) ${ }^{9}$ 
Com a vitória eleitoral de Lula em outubro de 2002 abriu-se um ambiente de "menor" perseguição aos movimentos sociais de luta pela terra, uma conjuntura política "mais" favorável para o debate sobre a Reforma Agrária, ao mesmo tempo, que se criou uma expectativa em torno da questão Agrária de modo geral, se comparado aos últimos anos de governo de Fernando Henrique Cardoso.

Em entrevista para a Folha de São Paulo já no início do governo em 2003, João Pedro Stédile fez a seguinte análise ao falar do governo, e do papel do MST:

Vamos continuar ocupando propriedades rurais agora que o PT está na Presidência, "não para afrontar o governo Lula, mas para ajudá-lo a fazer a Reforma Agrária no país". Afirmou também que a direção nacional do movimento suspendera a ocupação de prédios públicos, pois, "mudou a orientação do governo e agora temos um governo simpático a Reforma Agrária”, justificou Stédile. Para ele, o governo do presidente Lula contribuíra para alterar a correlação de forças na questão da Reforma Agrária. (Folha de São Paulo,2003).

Logo nos primeiros dias de governo, a Reforma Agrária ocupou espaço de destaque na imprensa nacional, primeiro por conta da composiçáo do governo:

No caso da Reforma Agrária, as manchetes se davam em torno das indicaçôes para o INCRA e MDA. Vários artigos na imprensa escrita trataram das indicaçôes para os cargos de Superintendentes Regionais do INCRA nos estados. Os ruralistas na época alegaram uma possível instabilidade política e aumento da violência no campo devido a ligação desses indicados com a CPT, MST e CONTAG. (Folha de São Paulo. São Paulo, 2003, p. A-7).

A Reforma Agrária voltou para o centro do debate político brasileiro, e com isto coloca dois sujeitos em permanente disputa sobre a posiçẫo do governo em relação a medidas a serem tomadas no tocante a Reforma Agrária. De um lado estavam os movimentos sociais em especial o (MST), que considerou o novo governo um aliado político, mas não deixou de intensificar suas açóes (CPT, 2003), no intuito de pressionar o governo a criar medidas que possibilitasse o avanço da Reforma Agrária, e de outro, estavam os ruralistas que se sentiam ameaçados e avessos a qualquer mudança no campo, rearticulando velhas e conhecidas entidades patronais, como são os casos das Confederação Nacional da Agricultura (CNA), Sociedade Rural Brasileira (SRB) e União Democrática Ruralista (UDR). Mas também, fizeram surgir outras, como é o caso do Primeiro Comando Rural, espirados no Primeiro Comando da Capital (PCC), (ALBUQUERQUE, 2006, p. 94).

E em meio as conturbaçóes políticas, em maio de 2003, o presidente Lula participou do Grito da Terra promovido pela CONTAG, onde na ocasião prometeu o assentamento de 60 mil famílias para o referido ano, atendendo prioritariamente as famílias acampadas ha mais tempo. Em novembro do mesmo ano, ele aprovou o II Plano Nacional de Reforma Agrária, que tinhas os seguintes pontos como medidas centrais: (a) extinção do Banco da Terra, mais isto não significou a extinção da Reforma Agrária de mercado, pois, havia setores no governo e nos movimentos sociais, que defendiam o crédito fundiário, inclusive a própria (CONTAG); (b) Retirada da página do MDA dos nomes de trabalhadores rurais anteriormente excluídos dos programas de assentamentos por terem participado de ocupaçôes de terras ou de prédios públicos; (c) Liberação de cestas básicas para famílias acampadas em todo país (ALBUQUERQUE, 2006, p. 96-97), (d) renegociação da dívida dos agricultores familiares; (e) fortalecimento das políticas de extensão rural para a agricultura 
familiar e assentamentos; (f) inovação nas açôes de obtenção de terras para a Reforma Agrária, utilizando mecanismo como o pagamento das dívidas dos proprietários devedores do INSS e de bancos públicos, negociadas em troca de terras. (IPEA, 2003, p. 99).

Para coordenar a construção da proposta de plano, o governo chamou Plinio de Arruda Sampaio, que de longe, era um grande conhecedor da Questão Agrária brasileira, que por sua vez, chamou outros grandes especialistas sobre o tema, montando uma equipe multidisciplinar, composta por, José Juliano de Carvalho Filho, Guilherme Delgado, Leonilde Medeiros, Pedro Ramos, Ariovaldo Umbelino de Oliveira, Bernardo Mançano Fernandes, Sérgio Pereira Leite e Fernando Gaiger.

A proposta foi intensamente discutida com os movimentos sociais. Nela, havia os objetivos, as diretrizes, as metas e os recursos para sua execução. A Proposta também apontava alterações necessárias nas normas e legislação, como a agilização e desburocratização das formas de obtenção de terras, a exemplo da revisão dos índices de produtividade.

Albuquerque descreveu o plano da seguinte forma:

A Proposta parte da constatação que a estrutura fundiária brasileira é caracterizada pela elevada concentração da propriedade da terra. Essa característica é responsável por relaçôes econômicas, sociais, políticas e culturais sedimentadas em uma estrutura agrária que impede o desenvolvimento, entendido na Proposta como sinônimo de crescimento econômico, justiça social e extensão da cidadania democrática à populaçáo do campo.

A Proposta argumenta que é no campo que se encontram os maiores índices de mortalidade infantil, de incidência de endemias, de insalubridade e de analfabetismo. (ALBUQUERQUE, 2006, p. 98).

A proposta ainda, reafirmava a desapropriação como principal mecanismo de arrecadação de terras, seguindo prerrogativa constitucional, com base no artigo 186 da Constituição Federal de 1988.

A proposta foi apresentada ao governo em outubro de 2003 e causou uma enorme turbulência dentro e fora do governo. Dentro do governo, pelas forças conservadoras, pela a bancada ruralista, e dentro da própria base do governo. Fora, por conta do alarde criado pela imprensa.

Percebendo as disputas dentro e fora do governo, no sentido de não deixar aprovar a proposta apresentado por Plinio e toda sua equipe, os movimentos sociais organizam uma marcha unitária das trabalhadoras e dos trabalhadores rurais, composta pelo o MST, Movimentos dos Pequenos Agricultores (MPA), CONTAG, Pastorais Sociais da Igreja Católica, ligadas a Conferência dos Religiosos do Brasil (CRB) e o Movimento Terra e Liberdade. A marcha seguiu até Brasília exigindo a aprovação do II Plano. Pressionado o governo respondeu. Embora o Plano aprovado não represente uma proposta intermediária, o que frustrou as expectativas dos movimentos sociais, que esperavam que fossem oficializadas as metas estabelecidas na Proposta preparada por Plínio.

Dado as disputas em torno da proposta apresentada, e do comportamento da base "aliada", o Plano aprovado ficou longe da proposta original. O Plano cresceu em intençóes, mas diminui na qualidade. O mesmo foi batizado de "Paz, Produção e Qualidade de Vida no Meio Rural".

Diante dos resultados insignificativos, metas não alcançadas e acordos não cumpridos, o restante do mandato do governo Lula foi pautado pelo discurso da melhoria aos assentamentos já 
realizados, e pela aliança entre o agronegócio e o poder judiciário, com o objetivo de criminalizar os movimentos sociais.

Em recente monografia sobre o tema da criminalização dos movimentos sociais, Gilvan Oliveira, da turma Eugenio Lyra/PRONERA/UNEB, assim definiu as formas desse processo de criminalizar os movimentos sociais:

Entre as formas utilizadas na tentativa de criminalizar os movimentos sociais, está a grande campanha de descredibilidade das lutas sociais, encabeçada pelas mídias sociais. Além do uso da força do Estado com o aparato policial, que tem reprimido veementemente as manifestaçóes; da pistolagem, que tem executado lideranças dos movimentos; do Poder Judiciário, que tem tomado decisóes contra lideranças e movimentos; e da criação de Leis que visam, além de dificultar o processo de Reforma Agrária, colocar na marginalidade quem vai de encontro ao modelo capitalista imposto. (OLIVEIRA, 2017, p. 60).

Talvez a fala de Plínio de Arruda Sampaio, durante a Conferência Terra e Água, sintetize a derrota política da Reforma Agrária no contexto do governo do presidende Lula. "É com tristeza que eu falo hoje, não consigo admitir que tenhamos assentado menos que o governo anterior, que era contra os trabalhadores" (MST, 2005. p.69).

\section{CONSIDERAÇõES FINAIS}

Diante do exposto ao longo deste trabalho, se faz ainda necessário fazermos algumas consideraçóes. Entretanto, não temos a pretensão de encerrar o debate, mas objetiva trazer uma síntese e propor alguns apontamentos e reflexôes para futuros debates e pesquisas.

Trazemos a seguinte constatação: O Brasil é um país com uma dívida histórica em relação ao processo de distribuição da terra. Ao longo da história, houve alguns momentos onde se ensaiou medidas de distribuição de terras, em especial com a pós redemocratização, que combinou na conquista da Constituição Federal de 1988, onde se estabeleceu mecanismos para a efetivação da Reforma Agrária.

Com base nestes mecanismos, fizemos a análise dos Planos nacionais de Reforma Agrária, e de programas de Reforma Agrária, onde extraímos que o Estado brasileiro não conseguiu efetivar sua concepção de justiça social no campo expressa na Constituição, por conta dos interessas das oligarquias locais, do latifúndio e também dos interesses estrangeiro.

Se constatou também que quando ouve algum processo de distribuição de terras, estes foram à custa de muitas lutas dos movimentos sociais.

E por fim, explicitamos como que a terra sempre foi utilizada para a manutenção do status quo, e que quando se ousou a propor uma Reforma Agrária, mesmo que nos moldes do capitalismo, a sociedade amargou com longos anos de repressão.

\section{REFERÊNCIAS}

ALBUQUERQUE, Valeria de Oliveira Reforma Agraria no governo Lula: uma analise do II Plano Nacional de Reforma Agraria Valeria de Oliveira Albuquerque. -Franca : UNESP, 2006 
A NOVA Reforma Agrária. Brasília: Gabinete do Ministério Extraordinário de Política Fundiária, 1999. Boletim de Políticas Sociais do IPEA n. 07, agosto de 2003, p. 99.

BRASIL. Ministério do Estado de Política Fundiária. Agricultura familiar, reforma agrária e desenvolvimento local para um novo mundo rural. Brasília, 1999.

CANUTO, A; LUZ, R. S. (Coord.). Conflitos no campo - Brasil. 2003. Goiânia: CPT Nacional, 2003.

CHAVES, Christine de Alencar. A Marcha Nacional dos Sem-Terra — um estudo sobre a fabricação do social. Rio de Janeiro: Relume Dumará, 2000. Acessado em: Revista de Direito Agrário, MDA|Incra|Nead|ABDA, Ano 20, n 19, 2007.

Desenvolvimento Rural. Mercados de terras no Brasil: estrutura e dinâmica / organizadores Bastiaan Philip Reydon. Francisca Neide Maemura Cornélio Brasília: NEAD, 2006. 444 p.; 21 x 28 cm. -- (Nead Debate; 7). Vários autores.

Entrevista à Folha de São Paulo, 16/06/2003, citado por Boletim de Políticas Sociais do IPEA, n. ${ }^{\circ} 7$, agosto de 2003.

Folha de São Paulo. São Paulo, 13/03/03. A-7, Caderno Brasil; ARRUDA.

PERES, joão. Corumbiara: caso enterrado/joão peres. Santo André, SP:Editora Elefante, 2015.

Manifesto da Terra e da Água In: o Brasil precisa de Reforma Agrária - as propostas dos movimentos sociais e as 'promessas do governo Lula'. São Paulo: Caderno de Formação n. 36. MST, março 2005.

MEDEIROS, L. S. Reforma Agrária no Brasil - história e atualidade da luta pela terra. São Paulo: Ed. Fundação Perseu Abramo, 2003.

NEPOMUCENO, Eric. O massacre - Eldorado do Carajás: uma história de impunidade. São Paulo: Editora Planeta do Brasil, 2007.

ORLANDI, Eni Pulcinelli. Discurso e leitura. São Paulo: Cortez, 2005.

OLIVEIRA, Gilvan. Movimentos sociais do campo, conflitos e novos repertórios sociais e os instrumentos jurídicos do estado no Brasil na atualidade. 2017, p. 60. Bacharel em Direito pela a Universidade do estado da Bahia 2017.

STÉDILE, J. P. (org.). A questáo agrária no Brasil: Programas de reforma agrária 1946-2003. São Paulo: Expressão Popular, 2005.

TAVARES, M. C. A questão agrária. Folha de São Paulo, São Paulo, 27/04/1997. DINHEIRO, seção Lições Contemporâneas. 